\title{
IT'S BROKE SO LET'S FIX IT: USING A QUASI- INQUISITORIAL APPROACH TO LIMIT THE IMPACT OF BIAS IN THE AMERICAN CRIMINAL JUSTICE SYSTEM
}

\author{
Raneta Lawson Mack*
}

\begin{abstract}
Swiss justice works in terms of clock-making, you don't give a fast flywheel the benefit of the doubt or a second chance, you prize up the case, look inside and try to set it back. ${ }^{1}$
\end{abstract}

\section{INTRODUCTION}

The character and quality of any system of justice must be measured by its pragmatism and mutability in the face of shifting societal ideologies and values. ${ }^{2}$ Long ago, the United States Supreme Court affirmed that "[o]urs is the accusatorial as opposed to the inquisitorial system. ${ }^{n 3}$ That concise declaration has been a constant refrain in decisional precedent and serves as the fundamental underpinning of the United States' criminal justice system. Our accusatorial tradition is anchored by a profound loyalty and desire to protect individual rights guaranteed by our Constitution coupled with an explicit rejection of inquisitorial tactics reminiscent of Star Chamber "jurisprudence." Chief among those fundamental protections is that no

* Associate Professor of Law, Creighton University School of Law. The author especially thanks Creighton University School of Law for providing a summer research grant to support this research project.

1. Sybille BedFord, The Faces of Justice 259 (1961). In her book, Bedford recounts her travels to five European countries (France, England, Germany, Austria, and Switzerland) and documents her first hand observations of each country's justice system in operation.

2. See id. at 101 (describing how the law "shapes, and expresses, a country's modes of thought, its political concepts and realities, [and] its conduct."); see also Edward Tomlinson, Nonadversarial Justice: The French Experience, 42 MD. L. REv. 131 (1983) (theorizing that striking the necessary compromise between individual rights and law enforcement is a central question for a criminal justice system because such a balance ultimately affects the system's efficiency and shapes society itself).

3. Watts v. Indiana, 338 U.S. 49, 54 (1949). For other cases reaffirming that principle, see Miller v. Fenton, 474 U.S. 104, 109 (1985); Malloy v. Hogan, 378 U.S. 1, 7 (1964); Rogers v. Richmond 365 U.S. 534, 541 (1961).

4. See Michigan v. Tucker, 417 U.S. 433, 440 (1974) (discussing how "[t]he privilege against compulsory self-incrimination was developed by painful opposition to . . . Star Chamber proceedings . . . which placed a premium on compelling subjects of the investigation to admit guilt from their own lips . . . ."); Watts, 338 U.S. at 54 (describing how the AngloAmerican system of justice has been characterized as accusatorial since "it freed itself from practices borrowed by the Star Chamber from the Continent whereby an accused was interrogated in secret for hours on end.").

The Star Chamber, which originated in the judicial branch of the 14th century King's Council, determined its procedures at its discretion and frequently used the oath ex officio which required suspects to swear to answer all questions put to them before they knew the nature of the interrogation. See generally LEONARD W. LEVY, ORIGIN OF THE FIFTH 
person shall "be deprived of life, liberty, or property, without due process of law." The substantive and procedural protections afforded defendants in criminal trials have evolved since our nation's founding. During the 1960s, however, the United States Supreme Court, under the leadership of Chief Justice Earl Warren, effectively revolutionized the nature and quality of the accusatorial system through proactive interpretation and application of the Due Process clause and its protections. ${ }^{6}$ To effectuate this transformation, the Court engaged in a level of judicial activism that ultimately "force[d] major changes in the established legal and social order." Thus "constitutional adjudication . . . became an instrument of reform," ${ }^{8}$ with the Court assuming "special judicial responsibility for values and groups not adequately represented in the political process."

The Warren Court's due process ideology breathed life and substance into the notion of an accusatorial system of justice as perhaps no other Court had done in the past and no Court has done since. ${ }^{10}$ Because this expansion of due process rights was concurrent with a period of intense social upheaval as the nation struggled with issues of race and civil rights, the jurisprudential enlargement of due process protections in the criminal context is inextricably intertwined with race and the expansion of civil rights. As a result, the legislative grant of basic civil rights and the contemporaneous judicial expansion of due process rights are often either consciously or

Amendment: The Right Against SElF-InCRimination 23-24, 101 (1968).

5. U.S. CONST. amend. V; see also U.S. CONST. amend. XIV (making the same fundamental protections applicable to the states).

6. See ARChibald Cox, The Court and the Constitution 179-80 (1987). Cox observes that because the "political process had become resistant to libertarian, humanitarian and egalitarian impulses," the Warren Court "came to be influenced by a conscious sense of judicial responsibility for the open and egalitarian operation of the political system." Id. at 179. For specific cases demonstrating the Court's proactive interpretation of the Due Process Clause, see Malloy v. Hogan, 378 U.S. 1, 6 (1964) (holding that "the Fifth Amendment's exception from compulsory self-incrimination is also protected by the Fourteenth Amendment against abridgement by the States"); Gideon v. Wainwright, 372 U.S. 335 (1963) (concluding that the Sixth Amendment guarantee of counsel is fundamental and essential to a fair trial and is therefore obligatory on the states by application of the Fourteenth Amendment); Mapp v. Ohio, 367 U.S. 643 (1961) (holding that the exclusionary rule is an essential part of the Fourteenth Amendment).

7. Cox, supra note 6 , at 182.

8. Id.

9. Id.

10. For example, the Court reformulated the law of confessions, developed standards governing the admission and exclusion of evidence when obtained by means of electronic surveillance, and forced closer scrutiny of standards relating to discovery. See, e.g., Katz v. United States, 389 U.S. 347 (1967) (establishing standards for electronic surveillance); Miranda v. Arizona, 384 U.S. 436 (1966) (establishing standards for police interrogation); Brady v. Maryland, 373 U.S. 83 (1963) (establishing standards relating to prosecutorial suppression of evidence favorable to the accused). 
subconsciously merged into a foreboding image of unprecedented rights and protections for minority criminal defendants. ${ }^{11}$ This imagery is sustained and, in many instances, exaggerated by a media that consistently depicts the visage of crime as a person of color. ${ }^{12}$

The reality, of course, is that the Warren Court's constitutional doctrine expanded due process rights for all criminal defendants without regard to race. Building upon that premise, it is conceivable that any person arrested has an equal opportunity to avail himself or herself of the substantive and procedural protections afforded by our accusatorial system of justice. Consequently, although perhaps not desirable, factually guilty criminal defendants would have an equal chance to escape punishment or, alternatively, receive a reduced punishment as a direct result of an encroachment upon one or more constitutionally protected rights. Despite these expanded protections and the perception that these protections confer unwarranted benefits on minority criminal defendants, numerous studies reveal that minorities and whites are afforded differential treatment at almost every stage of the criminal justice process, beginning with arrest and culminating, in some instances, in execution. ${ }^{13}$ Indeed, one of the more

11. See, e.g., Alexander Wohl, Metamorphosis: The Court, The Bill, and Liberty for All, 77 A.B.A. J., Aug. 1991, at 42 (discussing how concern for giving black citizens equal treatment and equal rights "spilled over" to fair treatment of black defendants in the criminal justice system); LAWRENCE TRIBE, AMERICAN Constitutional LAW v (1978) (predicting that the Warren Court will be remembered as a period of "exaggerated activism on behalf of individuals and minorities").

12. See, e.g., Robert Elias, Race, Crime and the Media, THE Humanist, Jan. 1994, at 3. Elias examined every general crime story appearing in Time, Newsweek, and U.S. News \& World Report from 1956 to 1991 and found that each magazine most frequently described and visually depicted blacks and other non-white minorities as criminals, even though these groups do not commit the majority of crimes. In contrast, the magazines described and pictured victims as mostly white people. See also Frederick H. Lowe, Group Aims to Change Portrayal of Black Men, ChICAGo SUN-TIMES, Aug. 18, 1993, at News 12 (noting how a Northwestern University study found that $77 \%$ of television stories about black men concern crime compared with $42 \%$ for white men).

13. See, e.g., Developments in the Law-Race and the Criminal Process, 101 HARv. L. REV. 1472 (1988). After comprehensively examining every component of the criminal justice system, this series of articles concludes that there is evidence that discrimination exists against African Americans at almost every stage of the criminal process. See also Robert D. Crutchfield et al., Analytical and Aggregation Biases in Analyses of Imprisonment: Reconciling Discrepancies in Studies of Racial Disparity, 31 J. RES. CRIME \& DELINQ. 166-82 (1994) (concluding on the basis of empirical studies that justice is by no means guaranteed for minorities in the criminal justice system); Norval Morris, Race and Crime: What Evidence Is There that Race Influences Results in the Criminal Justice System, 72 JUDICATURE 113 (1988) (opining that the law and order movement is, in operation, anti-black and antiunderclass); Alfred Blumstein, On the Racial Disproportionality of United States' Prison Populations, 73 J. CRIM. L. \& CRIMINOLOGY 1259 (1982) (comparing arrest rates to rates of incarceration and concluding that a significant portion of racial disparity can be attributed to racial discrimination). 
compelling statistics reveals that while three times as many blacks are arrested for crimes, there is a ratio of seven blacks to each white in prison. ${ }^{14}$ Moreover, observers predict that if the prison population continues to rise at its current annual rate of increase, then by the year 2020 , " 4.5 million African-American men and 2.4 million Hispanic men will be incarcerated [yielding] a prison population of minority men about five times as large as the prison population of all races combined today." 15

Clearly, these appalling statistics and predictions reveal that the reality of "due process" for minority criminal defendants is, very simply, one of being "processed" through the system. Furthermore, a careful examination of our criminal justice system discloses that this "processing" can, in part, be attributed to the myriad levels of discretion that arise throughout various stages of the criminal justice process. ${ }^{16}$ Discretionary decision-making inherently permits the interpolation of both subtle and overt bias and prejudice into the process. Thus, for certain categories of defendants, the expansive protections incorporated into our accusatorial system of justice ring hollow and meaningless when juxtaposed against the unfettered discretion that pervades the system.

From a scholarly perspective, it is neither unreasonable nor unprecedented to examine our criminal justice system and conclude that, in many respects, it is a microcosm of societal biases and prejudices. ${ }^{17}$ As a

14. U.S. Dep'T OF Just., Bureau of Just. Stat., Prisoners in 19941 (1995). The statistics reveal that the incarceration rate for blacks is 1471 per 100,000 black U.S. residents as compared to 207 per 100,000 white U.S. residents.

15. The Real War on Crime, The Report of the National Criminal Justice COMMISSION 106 (Steven R. Donziger ed., 1996) [hereinafter NCJC REPORT]. The National Criminal Justice Commission (NCJC), using the actual racial/ethnic makeup of prison and jail inmates in 1992, projected forward to the year 2020 given an average increase of eight percent per year in the total prison population. The NCJC notes, however, that this prediction is "obviously speculative." Id.

16. See Christopher Johns, Juvenile Justice Teaches Race Lesson, ARIzoNA REPUBLIC, Dec. 3, 1995, at $\mathrm{H} 3$ (discussing how discretion begins at the arrest stage for minority juveniles and, once in the juvenile justice system, "one discretionary decision influences others. The effect is cumulative."); Alfred Blumstein, Racial Disproportionality of U.S. Prison Populations Revisited, 64 U. CoLO. L. REV, 743, 746 (1993) (noting how with some crimes there is more room for discretion which also offers the opportunity for the introduction of racial discrimination); Developments in the Law: Race and the Criminal Process, 101 HaRv. L. REV. 1472, 1520 (1988) (discussing how racial bias can enter the system through a myriad of potential channels); William J. Bowers et AL., Legal Homicide: DEATH AS PUNISHMENT IN AMERICA, 1864-1982 (1984) (Bowers observes that discrimination does not occur only at the imposition of the death penalty, but as the result of a great number of discretionary decisions by prosecutors along the path of charging, indicting, and plea bargaining).

17. See, e.g., Michael Tonry, Race and the War on Drugs, 1994 U. CHI. LEGAL F. 25, 27 (1994) (arguing that "the War on Drugs, because of its implications for black Americans, should never have been launched" and that consequently "American drug policies should be 
result, many have argued for sweeping changes in various aspects of the criminal justice system in order to significantly decrease or eliminate the impact of those biases. ${ }^{18}$ None, however, have critically examined the possibility, and potential viability, of a radical shift away from our accusatorial system of justice as a remedial response to systemic bias. To frame the issue more specifically, would the incorporation of inquisitorial elements significantly reduce the level of discretion and result in more raceneutral outcomes in our criminal justice system $?^{19}$ This Article contends that a quasi-inquisitorial system of justice, patterned after the revised Italian Code of Criminal Procedure, would provide a more fair, equitable distribution of justice while also promoting the goal of seeking truth in the criminal justice system. ${ }^{20}$

To develop this theory, this Article, in part II, will examine some of the fundamental distinctions between accusatorial and inquisitorial systems of justice through an examination of the ideologies and values that support each system as well as the roles and responsibilities of the primary players in each system. Then, in part III, this Article will discuss some of the more salient features of the Italian criminal justice system and, more specifically,

radically altered"); Placido G. Gomez, The Dilemma of Difference: Race as a Sentencing Factor, 24 GoldEN GATE U. L. REV. 357, 380 (1994) (discussing how race should be considered a mitigating factor to depart from sentencing guidelines to compensate for the impact of racism throughout the criminal justice system); Bryan A. Stevenson \& Ruth E. Friedman, Deliberate Indifference: Judicial Tolerance of Racial Bias in Criminal Justice, 51 WASH. \& LEE L. REV. 509, 515 (1994) (arguing that one response to bias and discrimination in the criminal justice system is the elimination of the exclusion of people of color from jury service through peremptory strikes); Blumstein, supra note 16, at 759-60 (observing that there is a high rate of intervention with blacks in the criminal justice system and concluding that our nation's stability depends upon our ability to identify why this occurs and find a means to redress the problem); Sheri Lynn Johnson, Racial Imagery in Criminal Cases, 67 TUL. L. REV. 1739, 1804 (1993) (discussing how "to ameliorate the effects of racial imagery on criminal trials" and proposing either an ethical provision or a race shield statute that would forbid the use of such imagery).

18. See Johnson, supra note 17.

19. The term "inquisitorial" has significant historical baggage in that it evokes images of heresy persecutions and is surrounded "with an aura of dread and mistrust." Mirjan Damaška, Evidentiary Barriers to Conviction and Two Models of Criminal Procedure: A Comparative Study, 121 U. PA. L. REV. 506, 557 (1973). In its generic sense, however, and as it is used in this Article, it connotes a procedure in which the judge is expected to take the fact-finding initiative both before and during the trial. The term "inquisitorial" thus signifies that the court performs the task of inquiring. See, e.g., John H. LANGBEIN, CoMparative CRIMINal PROCEDURE: Germany 1 (1977); Gerhard O.W. MuEller, The Position of the Criminal Defendant in the United States of America, in THE ACCUSED: A COMPARATIVE STUDY 87 (J.A. Coutts ed., 1966).

20. As will be explored more completely later in this Article, a quasi-inquisitorial system is one in which the basic accusatorial structure is retained and modified by the infusion of corrective inquisitorial elements. See infra notes 154-173 and accompanying text. 
the Italian Code of Criminal Procedure as a theoretical model for transformation of our accusatorial system. Finally, in part IV, this Article will systematically analyze how the goals of impartiality and fairness might be more aptly promoted through the adoption of a quasi-inquisitorial system of justice.

\section{ACCUSATORIAL V. INQUISITORIAL}

A critical examination and comparison of accusatorial and inquisitorial systems of justice necessarily begins with a discussion of the ideological and value-laden belief systems that form the foundation of each system. ${ }^{21}$ The ideological component is a crucial and particularly revealing aspect of the analysis because it contributes to the overall cohesiveness and functioning of the system. ${ }^{22}$ While each system comprehends similar actors within the system, the role that each actor plays, and the core ideologies that underlie the allocation of responsibilities accompanying those roles, differentiate each system. This section will identify the underlying ideologies and values of each system and substantively compare and contrast five major components of each criminal justice system: the police, the prosecution, the defense, the trier of fact, and the accused.

\section{A. Ideology and Values}

The paradigmatic accusatorial system of justice emphasizes protection of individual rights through the mechanisms of substantive and procedural

21. The discussion of inquisitorial systems is not meant to describe any particular country, and indeed, although inquisitorial systems provide fairly simple models of procedure, there is no single model to which all countries conform. See Thomas Volkmann-Schluck, Continental European Criminal Procedure: True or Illusive Model?, 9 AM. J. CRIM. L. 1, 10 (1981). This Article will describe some of the most common features of an inquisitorial system.

22. Since ideology constitutes the "glue" that holds the system together, piecemeal structural substitutions that are inconsistent with the ideological basis of a particular system are likely to be impracticable and ineffective. See, e.g., Myron Moskovitz, The O.J. Inquisition: A United States Encounter with Continental Criminal Justice, 28 VAND. J. TrANSNAT'L L. 1121, 1145 (1995). In his article, Moskovitz presents a dialogue between lawyers from the United States and Europe which compares their respective justice systems. At one point in the conversation, one of the characters observes:

People often look at an isolated aspect of a system, find it attractive, and assume that it may be transferred intact to another system. This is a mistake. Both the [accusatorial] and the inquisitorial systems are integrated systems. Each piece is affected and supported by every other piece. Transfer a piece without its support system, and it will probably fail or distort some other features that you didn't intend to affect.

Id. 
due process. ${ }^{23}$ In practical terms, once a criminal investigation has centered on a particular suspect, that individual is cloaked with numerous constitutionally guaranteed safeguards that attempt to "level the playing field" between the government and the accused. ${ }^{24}$ Ideologically, this translates into an orientation toward essential fairness throughout the criminal justice process which, in turn, engenders confidence that a just result will be obtained. $^{25}$ This essential fairness is manifested by the fact that even in instances when the defendant may have been caught "red-handed," the government must nevertheless shoulder the entire burden of gathering evidence against the accused, who may sit silently by taking full advantage of the presumption of innocence. ${ }^{26}$ Moreover, the accused is guaranteed the right to counsel who may assist in exercising each of the constitutionally guaranteed rights by challenging, among other things, the government's collection and presentation of evidence. ${ }^{27}$ In short, the accused is afforded maximum protection even at the expense of a factually reliable result. ${ }^{28}$ This illustrates that the principal objective of an accusatorial system is not necessarily to seek the truth, but to ensure that the accused has been treated fairly, and that correspondingly, the system has produced a fair and just

23. The U.S. Supreme Court has recognized that the accusatorial system distinguishes itself from the inquisitorial system because it provides protections in the form of the privilege against compelled self-incrimination, due process, and the presumption of innocence. See, e.g., Miller v. Fenton, 474 U.S. 104, 109-110 (1985) (due process protection in the context of police interrogation); Miranda v. Arizona, 384 U.S. 436, 459-60 (1966) (applying Fifth Amendment privilege against compelled self-incrimination to police interrogation); Rogers $v$. Richmond, 365 U.S. 534, 541 (1961) (the use of coerced confessions violates due process). See also Moskovitz, supra note 22, at 1189 (describing how rules such as Miranda and the exclusionary rule are fundamental rights that protect all of us and suggesting that "[i]f they make it a little harder to find the truth . . . it's well worth the price.").

24. See, e.g., Miranda, 384 U.S. at 467 ("We have concluded that without proper safeguards the process of in-custody interrogation of persons suspected or accused of crime contains inherently compelling pressures which work to undermine the individual's will to resist and to compel him to speak where he would not otherwise do so freely.").

25. See Moskovitz, supra note 22, at $1187-88$ (describing how justice emerges from every actor playing his role properly in the accusatorial system); but cf. Rollin M. Perkins, Absurdities in Criminal Procedure, 11 lowA L. REV. 297, 332-33 (1926). Perkins observes somewhat cynically that the accusatorial system allows all kinds of lawyer "tricks and schemes and surprises and concealments" assuming that the result of this combat of wits will be that right will prevail, provided only the rules of the game are carefully observed. Id.

26. See, e.g., Gordon Van Kessel, Adversary Excesses in the American Criminal Trial, 67 Notre DAME L. REV. 403, 483 (1992) (discussing how "[t]he failure of American defendants to testify has become so common that even the public rarely notices" when the defendant fails to take the stand).

27. See U.S. CONST. amend. VI; see also Van Kessel, supra note 26, at 464 ("Highly aggressive and contentious counsel who readily assert all possible objections and arguments make the trial process a long battle between semantic warriors which, though often entertaining, does little to further the trial's main objectives.").

28. Van Kessel, supra note 26, at 464. 
result. $^{29}$

One major irony that attends the accusatorial system and, in many instances, threatens the fairness of any outcome is the pervasiveness of discretionary decision-making. ${ }^{30}$ While the accusatorial system emphasizes fairness and due process, it also to a large extent relies upon the discretion of the actors within the system. Although such discretion clearly has the potential for abuse, particularly at the arrest and charging stages, the accusatorial system ostensibly relies upon its inherent adversarial nature as a self-correcting mechanism to ferret out such abuses. ${ }^{31}$

In contrast, the foremost objective of an inquisitorial system is to seek the truth..$^{32}$ In fact, so important is a factually reliable result that the system, in practice, relies heavily upon the most likely and accurate source of that information-the accused. ${ }^{33}$ Additionally, in furtherance of its truth seeking objective, the inquisitorial system "erects few evidentiary barriers that restrict the information the judge can consider in determining guilt." ${ }^{34}$ Therefore, "[c]ontinental systems of criminal justice have no equivalent of the Federal Rules of Evidence, since fixed evidentiary rules might lead to the exclusion of important probative evidence." ${ }^{\text {35 }}$ Similarly, "[c]onstitutional

29. See Damaška, supra note 19 , at 525. Damaška concludes that the great barriers to conviction established by the accusatorial system reflect a "conscious sacrifice of factfinding accuracy for the sake of other values." See also John Thibaut \& Laurens Walker, A Theory of Procedure, 66 CAL. L. REv. 541, 566 (1978) (observing that the accusatorial system is most effective in seeking "distributive justice"). Cf. Peter Arnella, Rethinking the Functions of Criminal Procedure: The Warren and Burger Courts' Competing Ideologies, 72 GEO. L.J. 185,198 (1983) (arguing that a truth discovery label "ignores the moral content and force of substantive guilt and the resulting need for a process that evaluates the moral quality of the defendant's actions").

30. See supra note 16 and accompanying text.

31. But cf. Van Kessel, supra note 26, at 463 (describing how many of the formal and technical rules, while "designed to guarantee a fair contest and just result, actually tend to delay and disrupt the presentation of evidence and to distract the jury from the discovery of the facts").

32. See, e.g., Moskovitz, supra note 22, at 1128 (the inquisitorial system is described as such because it is based upon the tribunal's duty to inquire to find the truth); Damaška, supra note 19, at 586 (singular importance of inquisitorial system is ascertaining the truth at trial); but cf. Arnella, supra note 29, at 196-97 (arguing that equating truth with historical fact assumes "a pure guilt or innocence model of criminal procedure").

33. See John H. Langbein, The Criminal Trial Before the Lawyers, 45 U. CHI. L. REV. 263, 283-84 (1978). Langbein, in describing why the accused is such an important testimonial resource, has concluded that, "[i]n general the accused will virtually always be the most efficient possible witness at a criminal trial. Even when he has a solid defense, the accused has usually been close to the events in question, close enough to get himself prosecuted." Id. at 283.

34. William T. Pizzi \& Luca Marafioti, The New Italian Code of Criminal Procedure: The Difficulties of Building an Adversarial Trial System on a Civil Law Foundation, 17 YALE J. INT'L L. 1, 7 (1992).

35. Id. 
exclusionary rules, such as those that have been read into the Fourth Amendment . . . are anathema." 36 Essentially then, the paradigmatic inquisitorial system reflects a singular focus on the ascertainment of truth that effectively subordinates the protection of individual rights.

One significant feature that supports the goal of a factually reliable result is the limitation on discretion within the system. Because the actors must perform certain crucial functions, the system exhibits a uniformity in the treatment and processing of offenders. ${ }^{37}$

In summary, an examination of each system and its accompanying ideologies and values demonstrates that portions of one system may not be successfully transported and grafted upon the other without a simultaneous reorientation of the values that underlie each system. The next sections will explore the specific actors and how their respective roles express the ideologies and values of each system.

\section{B. The Actors and Their Roles}

\section{The Police}

In an accusatorial system of justice, the police perform the primary investigative function. ${ }^{38}$ They are often the first point of contact for a suspect and, in general, determine whether any given encounter will culminate in an arrest. ${ }^{39}$ As part of their investigative role, the police may, within constitutional boundaries, detain and search a suspect and conduct searches of a suspect's home and other locations that may contain evidence of criminal activity. ${ }^{40}$ Additionally, the police may seek to obtain statements

36. Id.

37. See, e.g., id. at 9-10 ("The [inquisitorial system's] emphasis on uniform results manifests itself in a strong aversion to prosecutorial discretion." Similarly, "a system of plea bargaining like that existing in the United States is viewed as fundamentally inconsistent with the sacrosanct [inquisitorial] values of uniformity and truth.").

38. Contrary to popular belief, most police officers do not spend the bulk of their time fighting street crime. In fact, about $75 \%$ of police time is spent on routine patrol or administrative tasks in the police station. See DAVID BAYLEY, POLICE FOR THE FUTURE 1535 (1994).

39. NCJC REPORT, supra note 15, at 161 (discussing how police occupy a "frontline position" in the criminal justice system and "have the power to decide how to apply the law and determine the crime-fighting agenda of a community").

40. See id. (noting how the police have wide discretion to decide who will be stopped and searched and which homes will be entered). With respect to constitutional limitations on police-citizen contacts, see U.S. ConST. amends. IV and V. For judicial interpretations of those limitations, see generally California v. Acevedo, 500 U.S. 565 (1991) (establishing probable cause standard for searches of vehicles); Illinois v. Gates, 462 U.S. 213 (1983) (establishing probable cause standard for searches of homes); Terry v. Ohio, 392 U.S. 1 (1968) (establishing standard for detentions and searches of suspects). 
from the suspect and any witness to the crime concerning the criminal activity. ${ }^{41}$ Typically, once enough evidence has been gathered to support a charge against the accused, the police turn the investigation over to the prosecutor's office for further proceedings.

It is at this initial stage that the effects of discretionary authority emerge. While much of the police-suspect interaction is constitutionally circumscribed, ${ }^{42}$ no such limitations govern the decision to arrest. In fact, statistical evidence reveals-and most police officers "freely admit"-that race is used as a factor when police decide to follow, detain, search, or arrest. ${ }^{43}$ The improper use of racial stereotypes can result in "unfounded" arrests. Unfounded arrests usually include those arrests in which the suspect was innocent, there was inadequate evidence, or there was an illegal search or seizure. ${ }^{44}$ One empirical study of racial disparities and unfounded arrests discovered that "[f]or African Americans in California, the rate of unfounded arrests was four times greater than that of whites." 45 Additionally, in some urban areas, the rate is an alarming twelve times greater for African Americans. ${ }^{46}$ While there are alternative explanations for some of these disparities, the sheer magnitude of the difference, coupled with the casual admission by police officers, indicates that race is nonetheless a significant contributing factor.

Traditionally, under most inquisitorial systems, the bulk of investigatory responsibility rests with the public prosecutor or examining magistrate ${ }^{47}$ In this capacity, the prosecutor or examining magistrate is not

41. Officers must observe a specific set of guidelines in order to obtain constitutionally admissible evidence during an interrogation of the suspect. See Miranda v. Arizona, 384 U.S. 436,444 (1966) ("Prior to any questioning, the person must be warned that he has a right to remain silent, that any statement he does make may be used as evidence against him, and that he has the right to the presence of an attorney, either retained or appointed."). But cf. Oregon v. Elstad, 470 U.S. 298 (1985) (an initial failure to give Miranda warning does not render inadmissible statements made after the warning is given); New York v. Quarles, 467 U.S. 649 (1984) (establishing a public safety exception to Miranda).

42. See supra notes $40-41$ and accompanying text.

43. See Developments in the Law-Race and the Criminal Process, 101 HARv. L. REv. 1472,1496 (1988). Some officers believe that the use of race is a legitimate factor and point to the racial disparity in arrest patterns as supporting evidence. This argument, however, is patently circular since racial stereotypes influence police to arrest minorities, thereby creating the arrest statistics needed to justify the racial stereotype. See NCJC REPORT, supra note 15 , at 109.

44. NCJC REPORT, supra note 15 , at 109.

45. Id.

46. Id. In the city of Oakland, unfounded arrests of African Americans occurred at 12 times the rate of whites, while Los Angeles and San Diego had rates of seven and six times the rate of whites respectively. Id.

47. In France, the examining magistrate (juge d'instruction) is a judge who investigates the case before trial. In that capacity, she interviews all witnesses, writes reports, and oversees the collection of physical evidence and performance of any necessary scientific tests. 
acting as an advocate, but as an impartial fact-finder for the state. The prosecutor collects evidence, interviews witnesses, and compiles this information into a comprehensive case file (the dossier) which is then provided to the court for a determination as to whether there is "reasonable cause" to proceed to trial..$^{48}$ It is notable that recent modifications in some inquisitorial systems permit the police to take a more active role in pretrial investigations. ${ }^{49}$ Thus, while the prosecutor maintains a supervisory role, the police will usually conduct the actual -investigation which includes interviewing and interrogating suspects and collecting physical evidence. ${ }^{50}$ Since the determination of truth is the primary goal of the inquisitorial system, the investigatory stage is considered crucial because it allows for the initial collection of truth-producing evidence and the compilation of that evidence into a dossier which the judge will rely upon almost exclusively in conducting the trial and in reaching a decision. ${ }^{51}$

\section{The Prosecution}

In an accusatorial system of justice, the prosecutor's role, in theory, is to seek justice. ${ }^{52}$ As representative of the people, the prosecutor is responsible for evaluating the evidence and determining whether the facts merit charging the accused with a crime.$^{53}$ It has long been recognized that

The examining magistrate then prepares a dossier which she gives to the judge who will preside at trial. Moskovitz, supra note 22, at 1131. In Germany and Italy, the public prosecutor is in charge of the investigation. Van Kessel, supra note 26, at 421 .

48. Judicial review of the prosecutor's decision to charge is quite common in European countries. Van Kessel, supra note 26, at 422 n.69. As will be discussed later, this level of review establishes a significant check on prosecutorial bias in the decision to prosecute. See infra notes 145-47 and accompanying text.

49. See LANGBEIN, supra note 19, at 11-12 (discussing how the police now initiate and develop investigations, including interrogation of witnesses and the accused). See also Pizzi \& Marafioti, supra note 34, at 11 (observing that the Italian Code places the public prosecutor, rather than the police, in control of the investigation, although the police are at the prosecutor's disposal).

50. LANGBEIN, supra note 19, at 11-12.

51. The dossier is of such significance because it provides the "umbilical cord" that joins the investigatory and adjudicatory stages to the extent that the adjudication is often "a trial of the dossier rather than of the accused." J.A. Coutts, The Public Interest and the Interests of the Accused in the Criminal Process, in THE ACCUSED: A COMPARATIVE STUDY 1, 4 (J.A. Coutts ed., 1966).

52. The prosecutor is regarded as both an administrator of justice and an advocate, having a duty to seek justice, not merely to convict. See I ABA STANDING COMM. ON Ass'N STANDARDS FOR CRIM. JUSTICE, ABA STANDARDS FOR CRIMINAL JUSTICE $§ 3-1.1$ (2d ed. 1986). See also Berger v. United States, 295 U.S. 78, 88 (1935). In Berger, the Court acknowledged that while a prosecutor should prosecute with earnestness and vigor, the prosecutor's interest "is not that [he] shall win a case, but that justice shall be done." Id.

53. Prosecutors are governed by an ethical duty which provides that a prosecutor must 
the role of prosecutor carries with it very broad discretionary authority. ${ }^{54}$ Such discretionary control realistically makes it impossible for a prosecutor to treat every offense and offender alike. Instead, the prosecutor may make accommodations for certain mitigating or aggravating factors that impact the charging decision. ${ }^{55}$

Since myriad factors can affect the decision to prosecute, it is perhaps not surprising that biases and prejudices can infiltrate the decision-making process. ${ }^{56}$ In fact, the majority of empirical studies have concluded that racial discrimination can, and often does, play a role in the prosecutorial decision. ${ }^{57}$ For example, a study of 1017 homicide defendants in Florida found that crimes involving white victims and African American offenders were much more likely to be upgraded in severity by the prosecutor. The more serious charges often resulted in a more aggressive prosecution and lengthier sentences. The study also found that crimes involving African American victims and white offenders were more likely to be downgraded. ${ }^{58}$

At trial, the adversarial mechanics of the accusatorial system become apparent as the prosecutor marshals evidence against the defendant in an effort to prove the case beyond a reasonable doubt. ${ }^{59}$ As in the pretrial stage, the prosecutor acts as agent and attorney for the people, and typically this role becomes even more pronounced and adversarial in the context of the trial when it is clear that the defendant has chosen to put the prosecution to

not institute criminal charges "when he knows or it is obvious that the charges are not supported by probable cause." MODEL CODE OF PROFESSIONAL RESPONSIBILITY DR 7103(A) (1984); MODEL RULES OF PROFESSIONAL CONDUCT Rule 3.8(a) (1984).

54. The capacity of prosecutorial discretion to provide individualized justice is "firmly entrenched in American law." 2 WAYNe R. LAFAVE \& Jerold H. ISRAEL, CRIMINaL PROCEDURE § 13.2(a), at 160 (1984). See also Bordenkircher v. Hayes, 434 U.S. 357, 364 (1978). In Bordenkircher, the Court acknowledged that, in our criminal justice system, the government retains broad discretion as to whom to prosecute and so long as there is probable cause to believe the accused committed the offense, "the decision whether or not to prosecute, and what charge to file or bring before a grand jury, generally rests entirely in his discretion." Id. Accord United States v. Batchelder, 442 U.S. 114, 124 (1979); Oyler v. Boles, 368 U.S. 448,456 (1962).

55. See, e.g., Wayte v. United States, 470 U.S. 598, 607 (1985) (reasoning that factors that affect the decision to prosecute, such as strength of the case, the general deterrence value, and enforcement policies and priorities, are not readily susceptible to judicial review).

56. The Supreme Court has also recognized the likelihood that biases may affect the decision to prosecute and has concluded that, although prosecutorial discretion is broad, it is not unfettered and is subject to constitutional restraints. See Batchelder, 442 U.S. at 125. Specifically, the decision to prosecute may not be "deliberately based upon an unjustifiable standard such as race, religion, or other arbitrary classification." Oyler, 368 U.S. at 456.

57. See Developments in the Law-Race and the Criminal Process, 101 HARV. L. REV. 1472,1526 (1988).

58. Id.

59. For a discussion of the considerable pressure faced by prosecutors to compile impressive win-loss records, see Van Kessel, supra note 26, at 442. 
its proof. ${ }^{60}$ It is likely that many prosecutors would concede that, at this stage, winning the case becomes at least as important as seeking justice. ${ }^{61}$

With respect to the potential impact of bias at trial, the various components of the criminal trial process permit the actualization of the bias that begins with the initial decision to prosecute. Specifically, if a prosecutor elects to charge a defendant with more serious charges which carry stiffer penalties, it is likely that the prosecutor will aggressively prosecute the case in order to achieve conviction-the most favorable result. ${ }^{62}$ Aggressive prosecution tactics could include, among other things, an unwillingness to plea bargain, maximizing peremptory and "for cause" challenges during voir dire, and contentious cross-examinations. Each of these trial tactics is either consciously or unconsciously driven by the bias which is initially interposed by the decision to prosecute.

The prosecutor's pretrial responsibilities in an inquisitorial system are primarily limited to investigating the crime and preparing the dossier ${ }^{63}$ However, once the formal trial process begins, the prosecutor's role in the inquisitorial system is very much diminished as compared with that of the accusatorial system. As explored more completely below, because the judge takes the lead in questioning the accused and the witnesses, the prosecutor is often relegated to "asking occasional follow-up questions or suggesting other lines of inquiry." ${ }^{64}$ Perhaps more interestingly, the prosecutor does not have any apparent stake in the outcome of the proceedings. In her limited role, the prosecutor's responsibility is simply to "assist the tribunal in finding a just result, not to "win." "65

One critical distinction in this system, however, is that the prosecutor is "required to take action against all prosecutable offenses, to the extent there is sufficient factual basis." 66 This rule is commonly known as the rule of compulsory prosecution. Such an imperative essentially forbids the "prosecutor the discretion to refuse to prosecute in cases where adequate

60. See id. (arguing that prosecutors find it difficult to stand apart from the overall contentiousness of the adversary trial process and are likely to pursue their goal with "devotion equal to that of the defense").

61. See id. at 441 ("By the time a prosecutor brings a serious criminal case before a jury, it is exceedingly rare that the prosecutor has not become convinced of the defendant's guilt . . . [and] reasonably believe[s] that justice means a conviction . . . .").

62. See supra note 58 and accompanying text.

63. See supra notes 47-48 and accompanying text.

64. Pizzi \& Marafioti, supra note 34 , at 7 . For a discussion of the judge's responsibilities in an inquisitorial system, see infra notes 94-97 and accompanying text.

65. Moskovitz, supra note 22, at 1129. The fact that the prosecutor doesn't have any apparent stake in the outcome of the proceedings naturally reduces the level of contentiousness in the trial and results in a measure of tempered advocacy. See Van Kessel, supra note 26, at 442 .

66. LANGBEIN, supra note 19 , at 89. 
incriminating evidence is at hand." ${ }^{67}$ Additionally, and more importantly, it substantially minimizes the effect of external influences on the decision to prosecute ${ }^{68}$ In some countries, the rule of compulsory prosecution is supplemented by the authorization of citizen prosecutors, as well as the right to administrative and judicial review of the decision not to prosecute. ${ }^{69}$

\section{The Defense}

Defense attorneys bear the brunt of the most stinging criticisms directed toward the accusatorial system. This is chiefly because a defense attorney's role is to zealously represent his client, the accused. ${ }^{70}$ The accusatorial system accepts and, in many instances, expects that such zealous representation will not always have as its focal point a search for the truth. ${ }^{71}$ Instead, defense attorneys largely serve as the medium through which the accused exercises both substantive and procedural rights. ${ }^{72}$ In that capacity,

67. Id. See also Pizzi \& Marafioti, supra note 34, at 9-10 (If the prosecutor believes there are reasons for not prosecuting the case, the prosecutor must still file formal charges and then seek dismissal by a judge who has the authority to review the prosecutor's decision.).

68. See LANGBEIN, supra note 19, at 91-92. Langbein describes the dual function of the rule of compulsory prosecution as follows: "The rule of compulsory prosecution appeared simultaneously, both to rid the [prosecutorial] monopoly of its dangers for the citizen and to protect the prosecutor from political intervention. . . . The rule of compulsory prosecution frees him from demands for partiality from within the executive, while opening him to demands for impartiality from without." Id.

69. See generally id. at 100-05.

70. The ABA Model Rules of Professional Conduct provide that "[a] lawyer should act with commitment and dedication to the interests of the client and with zeal in advocacy upon the client's behalf." MOdel Rules of Professional CONDUCT Rule $1.3 \mathrm{cmt}$. (1984). Similarly, the Model Code of Professional Responsibility provides that a lawyer must "represent his client zealously within the bounds of the law." MODEL CODE OF PROFESSIONAL RESPONSIBILITY EC 7-1 (1984).

71. On the role of defense counsel in the accusatorial system, Justice Byron White observed that:

we also insist that he defend his client whether he is innocent or guilty....

[Further,] [d]efense counsel need present nothing, even if he knows what the truth is. . . . If he can confuse a witness, even a truthful one, or make him appear at a disadvantage, unsure or indecisive, that will be his normal course.

United States v. Wade, 388 U.S. 218, 256-57 (1967) (White, J., dissenting in part and concurring in part); see also William B. Enright, The Much Maligned Criminal Lawyer and/or the Stake of the Profession in Criminal Justice, 46 CAL. ST. B.J. 720, 723 (1971) (describing the role of defense counsel as one of a gladiator battling for victory in which guilt or innocence is irrelevant).

72. Prior to trial, a defense attorney is obligated not only to counsel the defendant, but also to "discover" the prosecutor's case against the defendant, collect evidence that supports any theory of the defense, and challenge any constitutional violations that may have occurred during the pretrial stage. This latter responsibility essentially ensures that the police and the prosecution have meticulously observed all of the constitutional protections afforded the 
defense attorneys perform such an exceptionally important role in the accusatorial system that the United States Supreme Court has established that the right to counsel is one of the fundamental rights that inheres in an accusatorial system of justice. ${ }^{73}$

At trial, defense attorneys become a part of the "ritualized aggression" that characterizes the adversarial trial process. ${ }^{74}$ As one commentator observed, "[f]or defense attorneys, courtroom victory usually translates into obtaining an acquittal," 75 and "[p]ursuing acquittal of the guilty while avoiding presentation of clearly perjured testimony is admired as one of the greatest achievements of the advocate's art." 76

In inquisitorial systems, the defendant, prior to trial, is also entitled to counsel and certain other substantive protections. ${ }^{77}$ However, unlike the accusatorial system, the responsibility of a defense attorney is conjoined with a search for the truth. In furtherance of that goal, defense counsel generally assists the investigation by advising the accused to answer truthfully ${ }^{78}$ Thus, although every defendant has a right to counsel, counsel is considered an important instrumentality in the search for the truth rather than an impediment to that goal.

At the trial stage, the defense counsel's role, like that of the prosecutor, is similarly limited. Practically speaking, defense counsel's participation is required only if he believes that the tribunal has somehow overlooked or misrepresented crucial evidence. In that rare instance, defense counsel may present additional witnesses and testimony in the defendant's behalf. ${ }^{79}$ Consistent with an emphasis on a search for the truth, defense counsel generally does not perceive the trial process as a win-lose

accused.

73. See Gideon v. Wainwright, 372 U.S. 335 (1963) (establishing that the Sixth Amendment right to counsel is fundamental to a fair trial and requires the appointment of counsel for indigent defendants); see also Argersinger v. Hamlin, 407 U.S. 25 (1972) (extending Gideon to any offense for which a sentence of imprisonment is authorized).

74. Van Kessel, supra note 26, at 435 (quoting SEYMOUR WiSHMAN, CONFESSIONS OF A CRIMINAL LAWYER 201 (1981)).

75. Id.

76. Id. at 436.

77. Id. at 412 (describing how nearly all continental countries now afford the accused the right to counsel, provide a form of the right to silence, and establish a presumption of innocence); see also Pizzi \& Marafioti, supra note 34, at 8 ("While the defendant has a right to refuse to answer any questions, such refusals are exceptional . . . .").

78. See Moskovitz, supra note 22, at 1138; MIRAN DAMAŠKA, THE FACES OF JUSTICE AND STATE AUTHORITY 127-29 (1986) (observing that the presumption in inquisitorial systems is that the defendant should cooperate with the trial judge and answer questions completely).

79. Langbein noted that while "[d]efense counsel usually does a little more questioning of witnesses at trial [than the prosecutor does,] he too is customarily a relatively passive forensic performer." LANGBEIN, supra note 19, at 64 (quoting John H. Langbein, Controlling Prosecutorial Discretion in Germany, 41 U. CHI. L. REv. 439, 448 (1974)). 
proposition, and accordingly does not have any apparent stake in "winning" a particular case. ${ }^{80}$

\section{The Trier of Fact}

Perhaps the most striking and influential distinction between the two systems of justice lies in the role of the trier of fact. In an accusatorial system, the judge acts as an umpire or referee, guaranteeing that all participants are playing by the rules. ${ }^{81}$ The judge must remain impartial throughout the proceedings and intercedes only to decide various evidentiary matters as they are submitted by the parties. ${ }^{82}$ Typically, the judge does not otherwise comment on the strength or weakness of the evidence and asks questions of the witnesses only in exceptional circumstances. ${ }^{83}$ Judges in the accusatorial system are thus passive umpires in the trial process.

In instances in which she must also act as the trier of fact, the judge weighs the evidence as presented by the parties, applies the relevant law, and renders a decision as to guilt or innocence. In theory, the judge has no stake in any particular outcome of a trial. ${ }^{84}$

When the defendant elects to exercise the constitutional right to trial by jury, the accusatorial system provides a mechanism whereby lay citizens are selected to participate in the decision-making process. ${ }^{85}$ After an initial

80. The reason that lawyers in an inquisitorial system do not share the same commitment to winning their cases as their accusatorial counterparts is that the judge typically dominates the proceeding, and the lawyers do not regard the case as theirs to win. See Van Kessel, supra note 26 , at 442 .

81. Id. at 429. For a historical perspective on the development of the passive judiciary, see generally SiR PATRICK DEVLIN, TRIAL BY JURY (1966) (observing that a lack of trust in an active judiciary can be traced to colonial times when citizens were hostile toward judges who served at the pleasure of the Crown).

82. See Van Kessel, supra note 26, at 429.

83. See FED. R. EVID. 614. This rule grants judges the authority to call and question witnesses. This authority, however, is rarely used and is "often discouraged by reversals." Van Kessel, supra note 26, at 429.

84. But see William J. Brennan, Jr., The Bill of Rights and the States: The Revival of State Constitutions as Guardians of Individual Rights, 61 N.Y.U. L. REV. 535, 551 (1986). Justice Brennan opines that state judges are often more immediately subject to majoritarian pressures than federal court judges and are correspondingly less independent than their federal counterparts. Id.

85. See U.S. CONST. art. III, $\S 2$ ("The trial of all crimes except in cases of impeachment shall be by jury . . . ."); U.S. CONST. amend. VI ("In all criminal prosecutions, the accused shall enjoy the right to a speedy and public trial, by an impartial jury of the State and District wherein the crime shall have been committed . . . ."); Duncan v. Louisiana, 391 U.S. 145, 149 (1968) ("Because we believe that trial by jury in criminal cases is fundamental to the American scheme of justice, we hold that the Fourteenth Amendment guarantees a right of jury trial in all criminal cases which . . . would come within the Sixth Amendment's guarantee."). 
screening for bias or partiality, lay jurors are expected to weigh the evidence, apply the law, and return a verdict as to guilt or innocence. ${ }^{86}$ The jurors' responsibilities mirror those of the judge in an accusatorial system. The critical difference, however, is that almost all lay jurors lack education and training in the intricacies of law. ${ }^{87}$ Consequently, they must be "instructed" on the relevant law and its various complexities in the criminal trial process. ${ }^{88}$ This difference is significant in the sense that it provides a basis for confusion and misapplication of legal standards as well as an opportunity to inject a multitude of societal biases and prejudices into the decision-making process. ${ }^{89}$ Notwithstanding the greater likelihood of bias, the accusatorial system places such confidence in the jury system that, except for very limited circumstances, a jury's decision is considered sacrosanct. ${ }^{90}$

Once there has been a determination of guilt, the judge is responsible for determining the sentence. Using the prosecutor's sentencing recommendation as a baseline and considering any mitigating or aggravating

86. This initial screening is accomplished through the voir dire process which allows prospective jurors to be questioned by the court or counsel as to any biases or prejudices that might impede the jurors' ability to weigh the evidence in an impartial manner. But $c f$. Irvin v. Dowd, 366 U.S. 717 (1961). In Irvin, the Court concluded that jurors were not required to be totally ignorant of the facts and issues involved. Instead, the Court reasoned that "[i]t is sufficient if the juror can lay aside his impression or opinion and render a verdict based on the evidence presented in court." Id. at 723.

87. See, e.g., LANGBEIN, supra note 19, at 119 ("In common law systems lay judges sitting as the jury formulate a verdict without the participation of legally trained persons and render the verdict without stating reasons."); see also Steve Bertsch, Fair Verdict Likelier from Random Jury, WASHINGTON TIMES, Oct. 10, 1994, at 18 (discussing how the current jury system actively eliminates the most knowledgeable and well-informed individuals because they are difficult to convince of a bad case).

88. Describing the process of instructing the jury, Judge Curtis Bok wrote, "[j]uries have the disadvantage . . . of being treated like children while the testimony is going on, but then of being doused with a kettleful of law during the charge that would make a third-year law student blanch." CuRTIS BOK, I Too, NiCODEMUS 261-62 (1946).

89. Sir Patrick Devlin, in discussing the English jury, concluded that trial by jury promotes justice by a device in which a "large body of [anonymous] men . . . to whom the law means something but not everything . . . give their decision in a word and without reason." DEvlin, supra note 81 , at 154 . Of course, the ability to do justice also grants the power to do injustice. See also Moskovitz, supra note 22, at 1180 (explaining that although it is important that the law be certain, consistent, and predictable, "the jury [system] runs counter to these objectives" in that jurors are untrained novices, unpredictable, and appear to have wide discretion).

90. It has been long settled that juries cannot be compelled to provide any rationale for their decisions. See, e.g., Clark v. United States, 289 U.S. 1, 17 (1933) (acknowledging that the rule that no juror shall be questioned for any verdict rendered is based upon an ancient principle); Dunn v. United States, 284 U.S. 390, 407 (1932) ("The law does not permit investigations into the deliberations of juries for ascertainment as a matter of fact upon what considerations verdicts are reached; the soundness of that rule has never been questioned."). 
evidence, the judge determines the defendant's sentence. ${ }^{91}$ With the advent of sentencing guidelines, the judge's discretion has been curtailed in favor of mandatory sentences for certain offenses or offenders. ${ }^{22}$ The potential for bias in the sentencing process is obvious when the judge is permitted to utilize discretion in weighing aggravating or mitigating factors. But this potential is perhaps not as apparent when sentencing occurs under the auspices of sentencing guidelines or mandatory minimum sentencing which would presumably require that like offenders be punished in a like manner. Notwithstanding the superficial appearance of fairness in guidelines and in mandatory minimum sentences, studies have shown that, because of the nature of the underlying criminal conduct that is encompassed by the sentencing guidelines, minorities often receive disproportionately longer sentences than whites who have engaged in similar criminal conduct. ${ }^{93}$

91. The sentencing process is a critical stage of a criminal proceeding and is governed by Due Process requirements. Although a "defendant has no substantive right to a particular sentence. . . . [he] has a legitimate interest in the character of the procedure." Gardner v. Florida, 430 U.S. 349, 358 (1977); see also Williams v. New York, 337 U.S. 241, 247 (1949) (recognizing that a sentencing judge must have access to the "fullest information possible concerning the defendant's life and characteristics.").

92. The Sentencing Reform Act of 1984 provided that the United States Sentencing Commission must promulgate binding sentencing guidelines for federal offenses. The principal goals of the guidelines were to eliminate the great variation among sentences for persons similarly situated and convicted of the same offense and to eliminate the uncertainty about the length of time a person would actually spend in prison. The 98th Congress passed the Sentencing Reform Act of 1984 as part of the Comprehensive Crime Control Act of 1984. Sentencing Reform Act of 1984, Pub. L. No. 98-473, 98 Stat. 1988 (codified as amended at 18 U.S.C. $\S \S 3551-3559,3561-3566,3581-3586$ (1988 \& Supp. III 1991) and 28 U.S.C. $\S \S$ 991-998 (1988 \& Supp. IV 1992)).

The Sentencing Guidelines were promulgated in 1987 and establish categories of criminal conduct, specific offense characteristics, and adjustments which are applied according to a formula to determine the sentence. See generally UNTTED STATES SENTENCING COMM'N, FEDERAL SENTENCING GUIDELINES MANUAL (1993).

93. Under federal law, possession of 50 grams of crack cocaine is a felony that carries a mandatory minimum sentence of ten years. See 21 U.S.C. $\$ 841$ (b)(1)(A)(iii) (1994) (any person convicted of possession with intent to distribute 50 grams or more of a mixture or substance which contains crack shall be sentenced to no less than 10 years in prison). A person would have to possess 5000 grams or more of powder cocaine to be given the same sentence. See 21 U.S.C. $\$ 841$ (b)(1)(A)(ii)(II) (1994). Almost $83 \%$ of crack cocaine arrests are of African Americans while approximately $40 \%$ of arrests for powder cocaine are of whites. It is therefore not surprising that under these laws, African Americans are being sent to prison in unprecedented numbers and for longer periods of time. U.S. DEP'T OF JUST., Bureau of Statistics, Sentencing IN THE Federal Courts: Does Race MatTER? The TRANSITION TO SENTENCING GUIDELINES 1986-90 97, 109 (1993).

It is notable that several judges have either refused to enforce the guidelines because of their discriminatory nature or resigned in protest. See Dennis Cauchon, Powder Cocaine v. Crack Cocaine: Balanced Justice?, USA TODAY, May 26, 1993 (Judge Alan Nevas remarked that the mandatory minimum sentences for crack cocaine are among "the unfairest sentences I have ever had to impose."). 
Judges in an inquisitorial system of justice are proactive in developing most, if not all, of the evidence during the trial. ${ }^{94}$ In order to facilitate this process, the presiding judge, prior to trial, gains familiarity with the case by studying the dossier prepared by the prosecutor or investigating magistrate. ${ }^{95}$ At trial, the presiding judge then proceeds to develop the evidence by questioning primarily the accused based upon the contents of the dossier. Because the judge is not bound by evidentiary and exclusionary rules that are common in an accusatorial system, this questioning process is generally unimpeded by the objections and sidebars that characterize the accusatorial system. ${ }^{96}$ Instead, the judge hears and develops all evidence relevant to the truth of the charge. ${ }^{97}$ It is important to note that because the pretrial focus is on pursuit of the truth, the question of guilt is almost always resolved at the pretrial stage when the accused often supplies the best evidence of guilt-a confession. ${ }^{98}$ Despite this pretrial determination, the trial is still a mandatory component because it is also the vehicle through which the accused can present mitigating evidence for purposes of sentencing. ${ }^{99}$

At the conclusion of the presentation of evidence in major cases, the presiding judge will join a mixed panel of professional judges and "lay assessors" who will apply the law, decide the defendant's guilt, and determine the appropriate sentence by a two-thirds majority. ${ }^{100}$ Because the system combines lay and professional judges, it provides a greater degree of confidence that lay jurors are being properly instructed in the law throughout the deliberation process. ${ }^{101}$

94. See LANGBEIN, supra note 19 , at 62 ("The presiding judge has the primary forensic role at trial ... he is the examiner-in-chief.").

95. Id. See also supra notes 47,63 and accompanying text.

96. See LANGBEIN, supra note 19, at 68-69.

97. $l$ d. at 70 ("The major constraint on the reception of evidence in a notionally unrestricted system of admissibility is the court's power to refuse to investigate irrelevant matter.").

98. Id. at 73.

99. See Moskovitz, supra note 22, at 1153 (discussing the fact that most inquisitorial systems do not recognize the guilty plea because it would be tantamount to permitting the parties to determine the truth which would usurp the court's authority to determine the truth of the charge and the sentence).

100. Lay assessors are citizens "selected at random from the population. The parties have no right to question them or to remove any of them, so long as they meet [the] minimal qualifications of age, citizenship, and the like." Moskovitz, supra note 22, at 1125 . The lay assessors sit and deliberate with the professional judges as a single panel. Id. See also LANGBEIN, supra note 19, at 119-46 (providing a comprehensive overview of the interactions between lay judges and professional judges in the German system).

101. Since there are no formal jury instructions, the professional judges normally explain the law to the lay judges in simple language and will even discuss it with them informally until they understand. Moskovitz, supra note 22, at 1126-27. After the deliberations, the "[1]ay judges vote before [the] professional judges." LANGBeIN, supra note 19, at 80; Pizzi \& Marafioti, supra note 34, at 9 (observing that a mixed panel permits "judges to benefit from 
Once the verdict and sentence are determined, one of the professional judges will issue a written opinion that explains in detail the factual and legal basis for the verdict. Additionally, because an inquisitorial trial determines both guilt and sentencing, the judgment will explain the sentence and its appropriateness under the circumstances. ${ }^{102}$ The fact that the tribunal must fully explicate its rationale for guilt and sentencing, combined with a thorough pretrial investigatory process, yields a trial result that is likely to be relatively free of discretionary whims. ${ }^{103}$

\section{The Accused}

In an accusatorial system of justice, the accused is cloaked with numerous constitutional rights once the investigation has focused on him as a suspect. ${ }^{104}$ Beginning in the interrogation room and continuing throughout the appellate process, the constitution guarantees the accused the opportunity to exercise those rights. In fact, the "constitutional shield" is so strong that the accused may even elect to waive a personal appearance at the trial and still be entitled to a full-blown trial on the merits. ${ }^{105}$ This result is entirely consistent with the fundamental notion that the defendant is not required to participate in the prosecution's case against him and that he therefore cannot be compelled to speak about his guilt or innocence. ${ }^{106}$ Hence, without an express waiver of certain protections, neither the judge nor the prosecutor may interview or question the accused about any aspect of the crime charged.

Further, if the defendant elects to remain silent at trial, the prosecution is expressly prohibited from commenting on that fact, and the trier of fact may not draw any inference from the defendant's decision to exercise this

the experience of laypersons while maintaining control over the development of evidence and the application of law").

102. See Moskovitz, supra note 22, at 1127.

103. The detailed opinion also facilitates the appeals process. See Pizzi \& Marafioti, supra note 34, at 8 ("Forcing the fact-finder to justify its conclusions facilitates the appeals process."). The fact-finder, however, does not disclose or publish voting splits or dissenting opinions. See LANGBEIN, supra note 19, at 81.

104. See generally U.S. CONST. amends. IV, V, and VI; Duncan v. Louisiana, 391 U.S. 145 (1968); Miranda v. Arizona, 384 U.S. 436 (1966); Gideon v. Wainwright, 372 U.S. 335 (1963); Mapp v. Ohio, 367 U.S. 643 (1961).

105. The Supreme Court has acknowledged that a defendant's right to appear at trial is a fundamental right. See Kentucky y. Stincer, 482 U.S. 730 (1987). That right may, however, be effectively waived by the defendant's voluntary absence, and the trial will continue in his absence. Taylor v. United States, 414 U.S. 17 (1973).

106. See U.S. CONST. amend. V; United States v. Hammad, 858 F.2d 834 (2d Cir. 1988) (discussing the impropriety of prosecutorial communications with a defendant in the absence of his counsel). 
constitutional protection. ${ }^{107}$ Thus, although the accused may be the sole party with access to, and an understanding of, the truth, the accusatorial system demands that the government seek alternative avenues to that truth. If those avenues yield less fruitful evidence, and the prosecution is therefore unable to prove the defendant's guilt beyond a reasonable doubt, then, consistent with the structure, priorities, and values of the accusatorial system, justice has been served, and the defendant must be released without regard to factual guilt or innocence. ${ }^{108}$ Lastly, as a further safeguard of the defendant's rights post-acquittal, the government is constitutionally prohibited from appealing the final decision of the trier of fact. ${ }^{109}$

Although the accusatorial system appears to promote and maximize the independence and control of the defendant, such protections may, in practice, contribute to and encourage a general reluctance on the part of the defendant to assist in a search for the truth. ${ }^{110}$ In the short term, this may seem a desirable outcome from the defendant's perspective. In the long term, however, a factually guilty defendant is precluded from accepting responsibility for his actions during the initial stages of the process and is therefore likely to be subject to the various levels of discretion that could ultimately produce a harsher outcome. For the factually innocent defendant, the failure to actively participate in a search for the truth may ironically produce a result similar to that of the factually guilty defendant. Once the wheels of the accusatorial machine begin to turn, factual guilt or innocence is relegated to the background as prosecution and defense attorneys begin to aggressively perform their prescribed roles of courtroom advocates and opponents. ${ }^{111}$

A defendant's cooperation and participation are actively encouraged in an inquisitorial system. ${ }^{112}$ Therefore, in preparing the dossier, the prosecutor is permitted to communicate directly with the accused concerning the events

107. Griffin v. California, 380 U.S. 609, 615 (1965) ("[T]he Fifth Amendment . . . forbids either comment by the prosecution on the accused's silence or instructions by the court that such silence is evidence of guilt."). The defendant may also require the court to provide an instruction that the jury must not give any evidentiary weight to her failure to testify. See Carter v. Kentucky, 450 U.S. 288 (1981).

108. See Van Kessel, supra note 26, at 451 (opining that "[o]ur strong attraction to the courtroom battle goes hand-in-hand with our diminished respect for the discovery of the truth").

109. See U.S. ConST. amend. V; Benton v. Maryland, 395 U.S. 784 (1969) (fundamental nature of the double jeopardy prohibition can hardly be doubted).

110. See Van Kessel, supra note 26, at $479-80$ (observing that, "[a]t times, the accused may appear set apart or even isolated from the trial process . . . [which] serves to both shield [him] from the proceedings and discourage him from participating in his defense.").

111. Id.

112. See Moskovitz, supra note 22, at 1138 (discussing how lawyers almost always encourage the pretrial cooperation of defendants because a refusal to answer could affect whether or not the defendant is detained pretrial as well as the ultimate nature of his sentence). 
surrounding the crime charged. This aspect of an inquisitorial system is fully consistent with a search for the truth because the accused is perceived to be the most likely person to possess information relating to the truth or falsity of the charges. ${ }^{13}$

While the accused is entitled to certain protections that mirror many of the protections afforded in an accusatorial system, these protections are rarely exercised in a manner that interferes with a search for the truth. ${ }^{114}$ It is usually at this stage that the factually guilty are encouraged to confess, and the confession is made a part of the dossier. ${ }^{115}$

At trial, the defendant's participation is further encouraged. In fact, the defendant is called upon to speak first, and "[t]he accused and the court engage in a direct and continuing dialogue without the intermediation of counsel." 116 Not only may the accused be called upon to respond to and question witnesses, but he ultimately provides the last word in his defense even if his defense counsel has already spoken for him. ${ }^{117}$ Because the question of guilt has likely been informally resolved during the pretrial investigation, the defendant's participation at trial primarily assists the tribunal in the sentencing determination. ${ }^{118}$ Once a decision has been rendered, extraordinarily "broad rights of appeal are extended to both parties." 119 Such a process seeks to ensure that the "punishment fits the crime" and that the tribunal has reached a reliable and just result.

\section{Summary}

As outlined above, each system is premised on a unique set of values and objectives that shape the roles and interactions of its participants. Nonetheless, even a brief overview reveals the inherent structural incongruities present in each system. Specifically, while the accusatorial

113. Id. (reasoning that the goal of an inquisitorial system is to find the truth and "the defendant is in a very good position to help . . . accomplish that task").

114. See supra notes 77-78 and accompanying text.

115. Interestingly, because the tribunal controls the trial process, the case, even after the confession, must still proceed to the trial stage. See supra note 99 and accompanying text.

116. LANGBEIN, supra note 19 , at 65 . Moreover, the accused is "neither required nor permitted to be sworn, hence he never risks perjury for the conduct of his defense." Id.

117. Id.

118. While the prosecutor may recommend a particular sentence, the court makes the final determination. Id. at 78 . Given that the prosecutor's advocacy role is limited, sentence recommendation is perhaps the most important step for a prosecutor at trial. Id.

119. Pizzi \& Marafioti, supra note 34 , at 9 . The authors point out that both parties can appeal the judgment's factual and legal conclusions and may introduce new evidence if the appellate court deems necessary. Moreover, not even an acquittal is final because the prosecutor may appeal if he believes the trial court mistakenly reached a judgment of not guilty. Id. 
system purports to grant the utmost protection to individual rights, the many levels of discretion inherent in the system may in fact undermine this protection for certain categories of defendants. By contrast, the inquisitorial system, with its emphasis on discovering the truth, places strict limitations on the conduct of its actors as a means of achieving that objective. Thus, while the accused may not enjoy maximum protection in an inquisitorial system, the discretionary constraints present there may indeed yield a result that is grounded in impartiality, fairness, reliability, and justice. The next section will explore the Italian Code of Criminal Procedure as a potential model for fine-tuning the American system of criminal justice.

\section{The Italian Code of Criminal Procedure}

\section{A. Introduction}

The Italian Code of Criminal Procedure (Codice di procedura penale) ${ }^{120}$ provides a compelling and relatively recent example of an attempt to "fine-tune" a criminal justice system by conjoining components of the inquisitorial model with elements of the accusatorial model. As such, it furnishes an analytical framework for the potential fine-tuning of the American accusatorial system of justice. It is perhaps a bit ironic that the American system, which was founded on principles of democracy and protection of individual liberty, can be further enhanced by drawing upon a system rooted in the infamous Inquisition and later "reformed" under the fascist dictatorship of Benito Mussolini. ${ }^{121}$ However, an overview of the Italian Code of Criminal Procedure reveals that its revisions have resulted in a process that "exhibits an accusatorial soul in a European body." 122

\section{B. The Need for Change}

The Italian criminal process is strongly rooted in the civil law tradition with its fundamental emphasis on discovering the truth. In light of this tradition, it possessed most of the accoutrements of a typical inquisitorial system. Yet because the 1930 Code was formulated during a fascist regime, it manifested many of the negative characteristics associated with inquisitorial systems. For example, the former Code provided for a pretrial examination

120. CODICE DI PROCEDURA PENALE [hereinafter C.P.P.] (Italy). Unless otherwise stated, this Article refers to sections of the new C.P.P., effective October 24, 1989.

121. The "reforms" were subsequently codified. See C.P.P. (1930) (Italy).

122. Ennio Amodio \& Eugenio Selvaggi, An Accusatorial System in a Civil Law Country: The 1988 Italian Code of Criminal Procedure, 62 TEMP. L. REv. 1211, 1212 (1989); but cf. Pizzi \& Marafioti, supra note 34 , at 3 (describing the result as a system “caught between two traditions"). 
phase (istruzione formale) during which a judge would investigate evidence against the accused. ${ }^{123}$ The examination phase would then be followed by a trial that developed all of the acquired evidence. ${ }^{124}$ Despite this requirement, however, the trial became a mere formality that was used to validate the conclusions drawn during the examination phase. ${ }^{125}$

Furthermore, the most egregious example of the true inquisitorial nature of the former Code was the fact that the examination phase was conducted in secret. ${ }^{126}$ Consequently, the defendant was precluded from knowledgeable participation and, in the shroud of secrecy, inquisitors often relied upon considerable pressure tactics to elicit witness testimony. ${ }^{127}$ The need to institute reform was clear under these circumstances, although initially the precise degree and direction of change required was uncertain. ${ }^{128}$ After various interim reforms, the Italian Parliament delegated formal responsibility for drafting a new code in $1974 .{ }^{129}$ Yet the path to reform was not straightforward, and fifteen years elapsed before the new Code of Criminal Procedure became effective. ${ }^{130}$ The next section will explore some of the significant components of the new Code.

\section{An Accusatorial Soul in an Inquisitorial Body}

Once formulated, the new Code represented a radical departure from the previous system. ${ }^{131}$ Although the Italian criminal process retains its European body, its soul now contains features that are distinctly accusatorial, such as preliminary hearings, cross-examinations, and plea bargaining. These new components, grafted into Italy's system in an attempt to give the parties more control over the proceedings, uncloak the previously secret pretrial proceedings and promote overall efficiency within the process. ${ }^{132}$ It is interesting that the Italian criminal process retains one major component that is uniquely inquisitorial-the rule of compulsory prosecution. ${ }^{133}$ As discussed previously, this rule assists in providing a crucial limitation on

123. C.P.P. art. 389 (1930).

124. Pizzi \& Marafioti, supra note 34 , at 4.

125. Id.

126. Id.

127. Id.

128. Another development that served as a catalyst for reform was the adoption of a new constitution in 1947. Id.

129. Id. at 4-5.

130. The time lapse was partially attributable to "a lack of consensus on the direction reforms should take." Id. at 5 n. 12.

131. The revised Italian Code of Criminal Procedure is quite comprehensive, comprising 11 books and 746 sections. Id. at $10 \mathrm{n} .44$.

132. Id. at 6-7.

133. See CostiTUZIONE [hereinafter Cost.] art. 112 (Italy). 
discretion notwithstanding the fact that the parties have gained a greater degree of control. ${ }^{134}$

Under the revised Italian Code of Criminal Procedure, the public prosecutor is responsible for pretrial investigation of a crime. ${ }^{135}$ Although the prosecutorial role is now more "adversarial" in the sense that he will advocate on behalf of the government at trial, the Code requires that, during the pretrial investigation, the prosecutor "also [assess] the facts and circumstances favoring the person under investigation." 136

Once suspected criminal activity is brought to the attention of the prosecutor, ${ }^{137}$ she must conduct the investigation within specific time limitations. ${ }^{138}$ Upon completion of the investigation, the constitutionally based rule of compulsory prosecution takes over and the prosecutor must obtain judicial approval (decreto di archiviazione) for the dismissal of a case. ${ }^{139}$ Beyond that important function, the judiciary also serves as a significant check on prosecutorial discretion during much of the preliminary investigation. From a newly acquired position of neutrality, the judge supervises the preliminary investigation and ensures impartiality at all stages of the investigation. ${ }^{140}$ Impartial judicial scrutiny of the preliminary investigation has important ramifications with regard to the independence of the prosecutorial function. Because the judge carefully monitors all critical phases of the prosecution, the potential for prosecutorial overreaching and bias is drastically minimized.

During the crucial stages of the pretrial investigation, the defendant is entitled to the assistance of counsel. ${ }^{141}$ Such a requirement effectively

134. See supra notes 66-68 and accompanying text; see also Amodio \& Selvaggi, supra note 122, at 1221 ("Under the new Italian Code, . . . it is still outside the power of the parties to enter, jointly or severally, a disposal of a criminal case as if it were a private law suit.").

135. C.P.P. art. 291. However, once the prosecutor has taken over a case, the police perform investigations under the specific direction of the prosecutor. Id. art. 348.

136. Pizzi \& Marafioti, supra note 34, at 11 (quoting C.P.P. art. 358).

137. C.P.P. art. 347 . This section provides that, within 48 hours of a victim's report, the police must inform the public prosecutor of the crime and send him all the information they have gathered. The prosecutor must then record the crime in the crime register (registro delle notizie di reato). Id. art. 335.

138. Id. art. 405. The preliminary investigation must be completed within six months of the date on which the crime was entered in the crime register. Id.

139. Id. arts. 408-11. Normally this occurs if the prosecutor believes that the evidence is insufficient to prove either that a crime was committed or that it was committed by a particular defendant. Pizzi \& Marafioti, supra note 34, at 11-12.

140. See, e.g., Pizzi \& Marafioti, supra note 34, at 12-13 (describing how the judge supervises the preliminary investigation and preserves impartiality throughout the process); Amodio \& Selvaggi, supra note 122, at 1218 ("The judge, in a strictly impartial position, supervises the prosecution of the case at every crucial step.").

141. This right extends to police interrogation without regard to whether the suspect is in custody. C.P.P. art. 350 . 
assures that investigatory activities are performed in a manner that respects the rights of the accused and attempts to place the suspect on relatively equal footing with the state. Another pretrial component that reflects a desire to achieve equalization of the parties within the process is the rule that mandates pretrial discovery of the prosecution's entire case. ${ }^{142}$ Such a broad discovery requirement represents an explicit rejection of "trial by ambush" and again demonstrates one of the Code's main purposes-to guarantee that the trial process will be dominated by a focus on developing the evidence and discovering the truth.

A version of the American plea bargaining process represents yet another manifestation of the accusatorial soul, albeit with some modifications. While the parties now have the capacity to forego trial and negotiate the sentence in the case, the judge must be satisfied that the "punishment fits the crime" in the sense that the negotiated settlement must comport with the substantive criminal law. ${ }^{143}$ It is notable that the plea bargaining process under the Italian system is limited to sentence negotiation rather than a bargaining of the substantive charges. ${ }^{144}$

The preliminary hearing (udienza preliminare), although nominally like its accusatorial counterpart, is essentially a pretrial judicial review of documents compiled during the investigation. ${ }^{145}$ After this in camera review and argument from both sides, the judge determines whether the case should proceed to trial. ${ }^{146}$ As a practical matter, most cases are set for trial because the judge may dismiss a case only under very limited circumstances. ${ }^{147}$

The influence of the accusatorial system is most apparent during the trial stage. Like its accusatorial counterpart, the Italian trial begins with opening statements by the parties. ${ }^{148}$ Similarly, during the trial, each party is responsible for developing the evidence by presenting witnesses and crossexamining other parties' witnesses. ${ }^{149}$ The defendant may speak at any point

142. Id. art. 416 .

143. Id. art. 444. The judge may reject a sentencing agreement if it is erroneous in law or inadequate in light of the seriousness of the crime.

144. Pizzi \& Marafioti, supra note 34 , at 22.

145. Id. art. 416. The defendant may also participate in the preliminary hearing by requesting an examination by the judge. He may not, however, be cross-examined. Id. arts. $64,65,421$.

146. Id. art. 422 .

147. The judge may only dismiss a case if she concludes that no crime actually occurred, the events described in the charge do not constitute a crime, or the defendant clearly did not commit the crime. Id. art. 425.

148. The public prosecutor begins, followed by lawyers representing any civil parties, followed by defense counsel. Id. art. 493 . The civil lawyers represent the victim, the victim's family, and other injured third parties who have an interest in the criminal case. The injured parties are allowed to protect any interest they may have by fully participating in the criminal trial. Id. arts. $493,496,498,523$.

149. Other accusatorial components include the presentation of closing statements and 
during the trial to challenge witness testimony and is granted the opportunity to make the final presentation at the conclusion of the trial. ${ }^{150}$ Although the defendant is no longer required to speak at trial and may elect to remain silent, a defendant who wishes to offer mitigating circumstances relevant to sentence determination must do so at trial. ${ }^{151}$

At the conclusion of the trial, the court issues a detailed written opinion that outlines its verdict and sentencing rationale (motivazione). ${ }^{152}$ The detailed opinion facilitates the exercise of broad appellate rights under the Code. These rights are virtually unchanged from the previous Code in that any party may appeal the decision of the court, and even the defendant may appeal an acquittal. ${ }^{153}$

\section{A Lesson From the Italian Model}

The fundamental aims in restructuring Italy's criminal justice system were 1) the removal of a secretive, judicially dominated, strict inquisitorial system and 2) the creation of an open, party-controlled, quasi-accusatorial system. That Italy has retained its inquisitorial body reflects that the core values and ideology of the system remain the same, but the priorities have shifted in response to societal demands.

One lesson to learn from the Italian model is that a criminal justice system can retain its core values and ideologies while simultaneously finetuning its components to address shifting priorities and competing societal demands. More specifically, as the next section will explore, the accusatorial system of justice in the United States can retain its emphasis on fairness and due process while contemporaneously changing its components to address the impact of unbounded discretion which contributes to differential treatment within the system. Drawing upon the Italian model, the United States can thus adopt a quasi-inquisitorial approach as a means of addressing these concerns.

rebuttals to those summations. Id. art. 523 .

150. Id.

151. Id. art. 533.

152. Id. art. 544 .

153. This anomaly results from the fact that the Italian system provides for five types of acquittals which range from a conclusion that no crime was committed to an acquittal because it was not possible to decide the case due to a procedural fault. A defendant may appeal to obtain a stronger form of acquittal. See Pizzi \& Marafioti, supra note 34, at 15. 


\section{The CASE For a QUASI-INQUISITORIAL SYSTEM OF JUSTICE}

\section{A. The Need For Change}

It would be idealistic to imagine that incorporating aspects of an inquisitorial system of justice would serve as a cure-all for the various ills that plague the American criminal justice system. Yet, it would be unfortunate if the difficult work of fine-tuning the system were eschewed simply because the results would be less than ideal. Without question, one of the more pressing concerns in our current justice system is the inequitable treatment of minorities throughout various stages of the criminal justice process. As articulated above, much of this unequal treatment is inherent in, and perpetuated by, a system that allows myriad levels of discretionary decision-making. ${ }^{154}$ Through this unchecked discretion, individual biases and prejudices coalesce to create an almost intractable form of systemic bias. A remedial "fine-tuning" alternative would not only retain the core ideologies and values that form the foundation of the accusatorial system but would also simultaneously curtail the unfettered discretion that permeates the system. A quasi-inquisitorial system would therefore incorporate a system of mandatory checks and balances modeled upon the Italian Code. In addition to remaining true to the spirit of due process and respect for individual liberty, such a system would also enhance the potential for overall fairness and truth-seeking throughout the process. The next sections will describe how such a system might be effectuated.

\section{B. The Police Function}

Under our current system, a suspect's initial contact with the criminal justice system is at the arrest stage. ${ }^{155}$ One method of limiting the impact of bias at this stage is to impose a mandatory reporting requirement on the police when they are made aware that a crime has been committed. ${ }^{156}$ Reporting the events of a crime to prosecutorial authorities can have a dual effect. First, it subjects police actions and policies to a greater degree of scrutiny, thus adding a level of oversight. Second, it results in increased numbers of non-minorities brought into the system, thus increasing the levels of objectivity and fairness at the inception of the criminal justice process. ${ }^{157}$

154. See supra note 16 and accompanying text.

155. See supra notes $39-41$ and accompanying text.

156. An analogous example is presented in the context of domestic violence cases. Many jurisdictions have incorporated mandatory arrest and "no drop" prosecution policies in order to achieve the larger common goal of eradicating domestic violence. See, e.g., Lisa Stansky, Organizing an Anti-Violence Offensive, 82 A.B.A. J., July 1996, at 49.

157. One explanation for the statistical disparity in arrest and incarceration rates is that 


\section{The Prosecutorial Function}

Upon receiving the report of criminal activity, prosecutorial authorities should incur a reporting responsibility similar to that of the crime register requirement in the Italian Code. ${ }^{158}$ As in the Italian system, the crime register would function as a record-keeping mechanism as well as the event which triggers certain time limitations for completion of the preliminary investigation. ${ }^{159}$ Perhaps more importantly, prosecutorial authorities should become more involved in the investigatory process, overseeing and controlling police actions. ${ }^{160}$ Because the prosecutor currently performs some investigatory tasks, such additional responsibility would require only a modest realignment of the prosecutorial function. Thus, commingling prosecutorial and police functions, imposing time constraints on the investigatory process, and requiring the prosecutor to probe exculpatory evidence would combine to produce a much tighter system of checks and balances, ultimately limiting opportunities by which subjective bias may be introduced into the investigatory and charging processes. With this limitation comes an assurance that similarly situated suspects will be treated in a fair, uniform manner.

As a final check on the prosecutorial function, our system should mandate compulsory prosecution. Because the current accusatorial system allows the prosecutor maximum control over the charging decision, it also permits maximum discretion. ${ }^{161}$ The initial decision to charge, and the corresponding determination of the nature of those charges, represent the most critical decisions in the criminal justice process. These decisions are outcome determinative to the extent that they can circumscribe subsequent stages of the process, particularly from the defendant's perspective. ${ }^{162}$ Given the considerable impact of the charging decision, it is tragically ironic that there are very few constraints on that authority. A rule of compulsory prosecution fashioned on the Italian model would remove this layer of discretion and expose the overall charging decision to judicial scrutiny. Such judicial oversight would not only insert a meaningful check on prosecutorial

a greater percentage of non-minorities are "selected out" of the system at this stage. For a discussion of the differences in arrest and incarceration rates, see supra notes 14-15 and accompanying text.

158. C.P.P. art. 335; see also supra text accompanying note 137.

159. C.P.P. art. 405 ; see also supra text accompanying note 138.

160. See supra notes $135-36$ and accompanying text.

161. See supra notes 54-58 and accompanying text.

162. For example, depending upon the initial charge, the defendant may be subject to pretrial detention, exorbitant bail requirements, increased attorney's fees, complex defense strategies, and harsher penalties. 
authority, but would substantially increase the likelihood of uniformity and objectivity in the charging process.

\section{The Defense Function}

Defense counsel in a quasi-inquisitorial system would act as an additional check on police and prosecutorial authority. Consequently, counsel would perform many of the same functions as required by the current accusatorial system. ${ }^{163}$ The role might be further expanded under a quasi-inquisitorial system to include the right to counsel whenever the police or prosecutor interrogate a suspect without regard to whether such questioning constitutes a custodial interrogation. ${ }^{164}$ Arguably, an expanded role for defense counsel could result in more obstruction and delay in the criminal process. The expanded role, however, must be conceptualized within the context of the entire quasi-inquisitorial system. If defense counsel and the defendant evince a higher level of confidence in the process as a result of a stricter system of checks and balances on the prosecutorial and police function-as well as comprehensive defense discovery prior to trial ${ }^{165}$-then the need for obfuscatory tactics is significantly diminished. Accordingly, the defense obligation might be refocused to encompass proposing legal alternatives that enhance truth seeking and issue resolution. While one disadvantage may be a restraint on the zealous advocacy that typifies the current accusatorial process, such a refocus would have profound advantages in that "justice" becomes less dependent upon one's ability to retain the "hired gun" and more closely aligned with the goal of seeking the truth and separating the guilty from the innocent. This could have an enormous impact with respect to decreasing the current dispensation of "unequal justice." Because every defense attorney is guaranteed access to certain information, the level of gamesmanship is removed, and counsel is free to embrace the role of counselor which increases the likelihood that guilty defendants will accept responsibility at the earliest opportunity. Coming to terms with guilt early in the process can conceivably influence the overall outcome, particularly with respect to sentence negotiation and mitigation.

\section{E. The Trier of Fact}

In a quasi-inquisitorial system, the judge would adopt a more active stance during the investigatory stage. As described above, during this stage,

163. See supra note 72 .

164. See supra note 141 and accompanying text. This would require an extension of the custodial interrogation requirement established in Miranda. See Miranda v. Arizona, 384 U.S. 436, 460 (1966).

165. C.P.P. art. 416 . 
the judge would incur oversight responsibilities that serve as a check on prosecutorial and police authority. ${ }^{166}$ Moreover, prior to trial, the judge would have exclusive authority to dismiss cases and approve sentence negotiation agreements. ${ }^{167}$

The nature of the judge's trial responsibilities would remain relatively passive as they now are under the current accusatorial system. At the conclusion of the proceedings, the judge would be required to set forth the court's decision in detail and include a rationale for the specific sentence. ${ }^{168}$ This would serve not only as a check on arbitrary and capricious decisionmaking but would also provide a concrete basis for appeal. ${ }^{169}$

The current jury system has considerable potential to inject the biases and prejudices of the community into a criminal trial. ${ }^{170}$ Even with the "controls" on partiality and bias in the current accusatorial process, the presence of the current jury system would nevertheless be anathema under a quasi-inquisitorial system. ${ }^{171}$ A realistic alternative to the current jury system would be a structure that introduces a greater degree of knowledge and professionalism into the process. One solution that represents a compromise between maintaining and eliminating the jury system is the implementation of a mixed panel system composed of professional and lay jurors. ${ }^{172}$ Under this configuration, the jury would be given concrete guidance in the law applicable to the case which will likely yield more rational and uniform decisions. As a further check on discretion, the mixed panel would also be required to issue a detailed written opinion.

166. See supra note 140 and accompanying text.

167. See supra notes $139,143-47$ and accompanying text.

168. C.P.P. art. 544; see also supra text accompanying note 152.

169. A more detailed opinion from the trial court could actually decrease the number of spurious and frivolous appeals because the court's rationale would provide the only basis for appeal.

170. See supra notes $87-89$ and accompanying text.

171. These controls include "for cause" and peremptory challenges. Even with these controls, however, some believe that peremptory challenges are an ineffective method of detecting bias. See, e.g., Mark Hansen, Peremptory-Free Zone, 82 A.B.A. J., Aug. 1996, at 26. In his article, Hansen describes how U.S. District Court Judge Constance Baker Motley has barred the use of peremptory challenges in her courtroom because they are a "per se [violation of] equal protection . . . an unnecessary waste of time and an obvious corruption of the judicial process." Id.

172. Professional jurors would include those who have formal training in the law. For recent discussions of jury reform, see, for example, Beth Taylor, What Makes Jury Tick? 12 Varied People; There's No Foolproof Formula For Picking and Persuading Jurors-Or Predicting Their Verdicts, ORLANDO SENTINEL, Mar. 17, 1996, at Gl (discussing how professional jurors, who are trained and paid to serve full-time, might be more capable of understanding complicated cases); Andrew Blum, Jury System Undergoes Patchwork Remodeling, NAT'L L. J., Jan. 22, 1996, at A1 (discussing the most "radical solution" of abolishing the jury system outright and replacing lay jurors with those trained as professional arbitrators). 


\section{F. The Accused}

Under a quasi-inquisitorial system, the accused would retain many of the fundamental substantive and procedural protections required under an accusatorial system. ${ }^{173}$ In addition to those personal rights, the accused would also obtain the tangible and intangible benefits of a system that has in place effective checks and balances that significantly limit the effects of bias and prejudice. While such a system might not encourage every guilty defendant to make a full confession prior to trial, it would enhance the overall perception of accuracy, efficiency, fairness, and justice within the system. This overall perception could have "trickle down" effects with respect to promoting accuracy in selecting those defendants deserving punishment as well as establishing a formidable structural deterrent to those considering criminal activity.

\section{CONCLUSION}

The American accusatorial system of justice is in desperate need of modification. Pervasive discretionary authority has produced an intolerable level of systemic bias that demands a remedial response. Such a response must include measures that provide effective checks and balances on that discretion while simultaneously preserving the ideological basis of the accusatorial system. This Article has demonstrated how the incorporation of an inquisitorial soul into the accusatorial body of our current system, and the consequent creation of a quasi-inquisitorial system, would provide significant constraints on discretionary authority while preserving the necessary emphasis on due process and protection of individual rights. Additionally, because the quasi-inquisitorial system eliminates many of the vagaries associated with boundless discretion, it would promote a truth seeking objective that would likely produce fair, uniform results and contribute to enhanced overall confidence in the American criminal justice system. 